\title{
Emotional reactions of the respondents compared to different ways of perceiving the square in front of the WICA building of the Lublin University of Technology
}

\author{
Olga Skoczylas \\ o.skoczylas@pollub.pl \\ Independent Architectural Design Studio, Lublin University of Technology, \\ Faculty of Civil Engineering and Architecture of the Lublin University of Technology
}

\begin{abstract}
The article presents a description of the research method and the results of research regarding the difference in the reception of space depending on the way it is perceived.

The research concerned one space (the square in front of the building of the Eastern Innovative Centre of Architecture at the Lublin University of Technology) and three different reception methods. One group of respondents was physically in the square, the other group virtually - with the use of virtual reality (VR) technologies, and the third one saw only pictures of the square. Each group of respondents chose the emotions with which they identified most from the semantic scale developed for this study. The results of the groups were compared, and the conclusions were presented in the summary.

The study was conducted to evaluate the possibility of using VR technology and photographs to study emotions that a given space evokes in its recipients.
\end{abstract}

Keywords: virtual reality, the perception of architecture, emotions in architecture, psychology of architecture, semantic differential

\section{Introduction - the aim of the study}

Virtual reality is currently used in many domains and for many purposes, among the others for the recreation of existing objects, in medicine, as a didactic support or for entertainment [Grabowski 2015, Oseńko 2017, Bil 2013, Pardel 2009]. Asanowicz [2014] says that it is possible to use VR for presentations and for designing directly in the virtual world.

Gardziński [2015] suggests the direction in which virtual cyberspace and its impact on / with a human may develop. Although he uses words with a negative axiological load for this purpose ("the loss of human being", "integrated switching system into the impersonal marginal world of fantasy", "atemporal and discarnate perfect virtuous shell"), he also propose a solution how to stay away from this black vision referring to the literary canon in the library of a contemporary architect [Żórawski 2008, Pallasma 2012, Zumthor 2010, Rasmussen 1999, Alexander 2008].

The concept of the psychology of architecture is quite a new area of science. The academic who studies this domain in Poland is Lenartowicz [1990, 2010, 1992]. His works were the contribution to this research.

The article is an attempt to answer the following questions: Is it possible to examine the emotions of the user of a space evoked by seeing it with their own eyes without the need to be physically present there? Does architecture and surroundings evoke emotions in people only when they are viewed on site or also when they are seen reproduced in a picture? And going further - can you use film frames to study the emotions triggered by buildings? Can a given test method (for VR) be used to test the reception of buildings that are to be constructed? What is the difference in emotional response depending on how one perceives space? 


\section{Research description}

Three ways of receiving space were examined - on-site verification, reception through virtual reality devices and traditional photographs.

Both traditional photographs and a 360-degree photo were taken at a similar time when the first group was on site. As a result, similar lighting and weather conditions were ensured to maximally eliminate the influence of external factors on the emotions of the respondents.

Subjects responded to the question "How do you perceive this place?". The survey contained 15 pairs of expressions. In each row, the respondents indicated one value on the 1-7 score scale. They chose a value closer to the left, if they supported the statement on the left side, and if they were more for a statement on the right, they circled a value closer to the right. The survey was based on the Osgood scale (semantic differential) [Osgood 1952].

The test site is the square in front of the WICA building (Wschodnie Innowacyjne Centrum Architektury). It is a place where respondents often pass. The square is used partly for a parking lot. There is the building of the Faculty of Civil Engineering and Architecture of the Lublin University of Technology and the back of the parish chapel of the Transfiguration of the Lord. The building is a perfect example of respect for the place [Wrana 2011, 2012a]. The building architects paid attention to the existing surroundings and the adaptation of the building to neighbouring buildings, especially to the earlier part of the Faculty of Civil Engineering and Architecture. The project manager, architect Jan Wrana claims: "The new form is a contemporary expression of the architecture of the $21^{\text {st }}$ century" [Wrana 2012b, 2013].

\section{Group results}

In total, 30 people took part in the study. They were divided into 3 groups, 10 people each. The surveys were solved individually and anonymously. The repondents were students of architecture of the second year of the first-degree studies and the first year of the second-degree studies.

Average results were calculated by adding all grades and dividing by the number of people. They were not rounded.

\section{Group 1 - comparative}

Group 1 was a comparative group. The respondents were physically in the square and they were making a questionnaire during their presence on site. The results are presented in the graph (Fig. 1.) Group 1 - comparative - the results of the study.

The square in front of the WICA building was assessed as a peaceful, safe, pleasant, interesting place that the respondents like.

\section{Group 2 - virtual reality}

The respondents of the second group were the ones who were virtually evaluating space. In picture (Fig. 2.) we can see a photograph that was used as a $360^{\circ}$ photo.

Due to the nature of the space perception during this study, the person conducting the research read the questions in the survey, and a respondent gave the answers orally. The respondents did not know their answers. The tests were carried out individually. The results are presented in the Fig. 4.

This group of students assessed the square as a peaceful, safe, pleasant, interesting place that they like. 


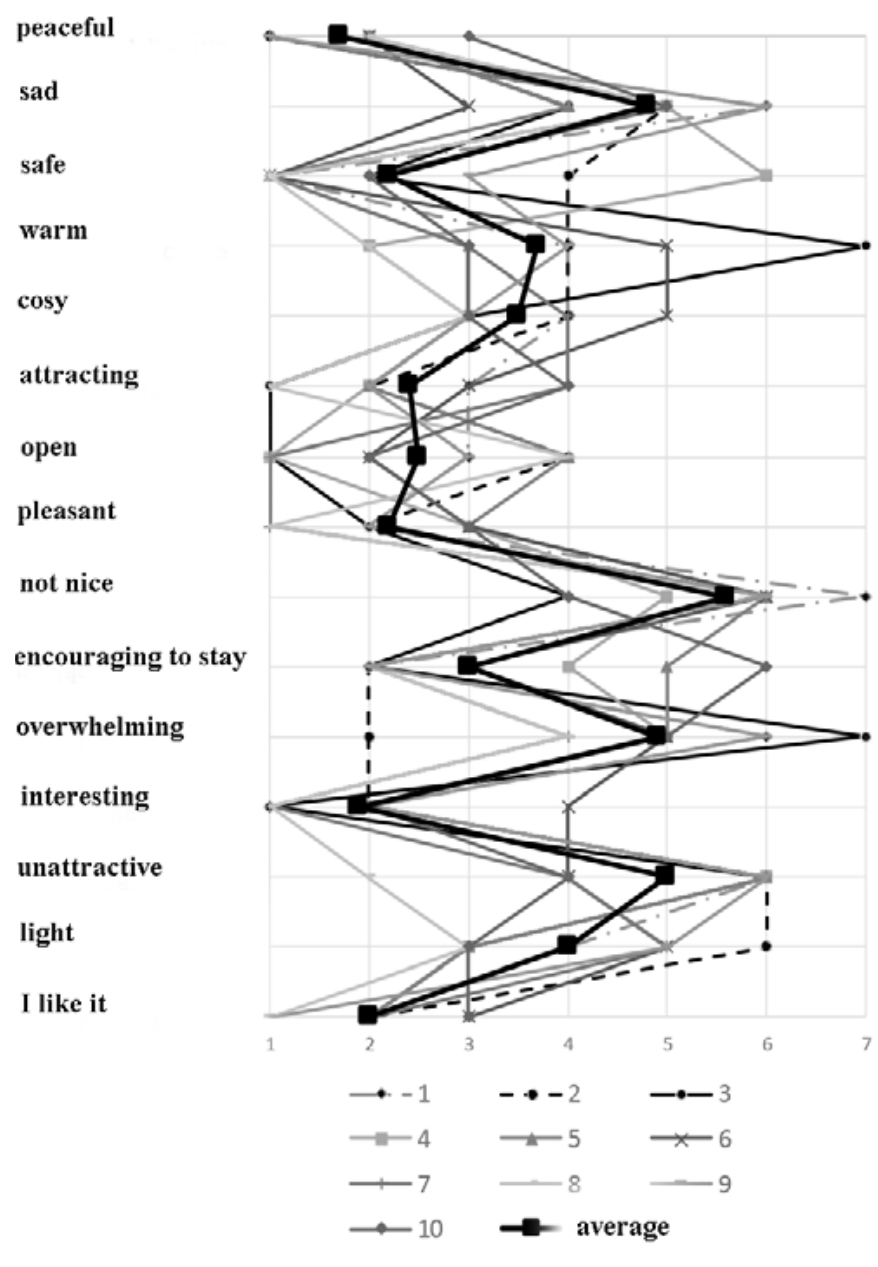

disturbing

cheerful

dangerous

cold

not cosy

repellent

closed

unpleasant

nice

not encouraging to stay

not overwhelming

boring

attractive

heavy

I don't like it

Fig. 1. Group 1-comparative - the results of the study. The line "average" shows the average results of the group (own elaboration)

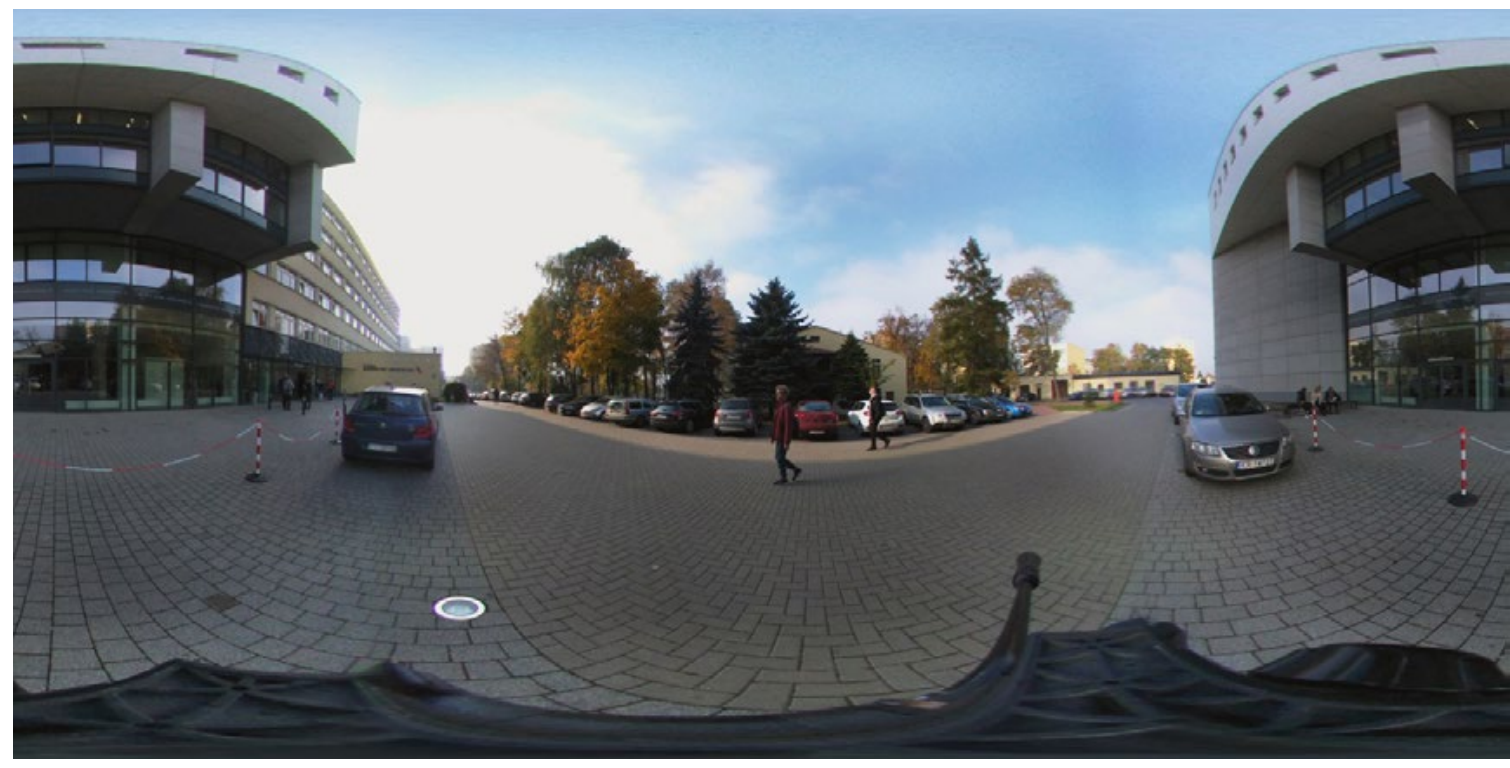

Fig. 2. Virtual photo presented to the respondents (author's own photography) 

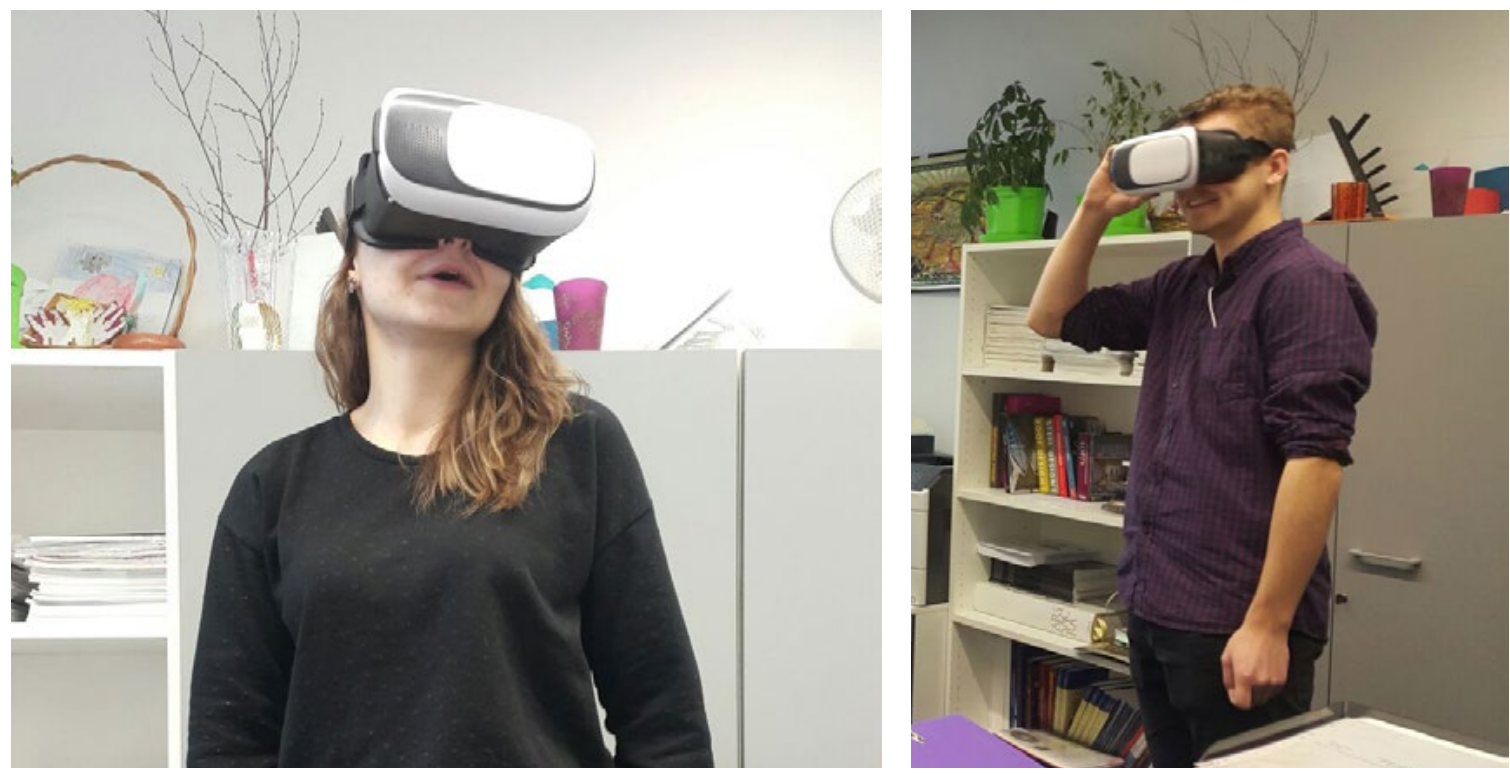

Fig. 3. Students during the survey (pic. M. Marszałowicz)

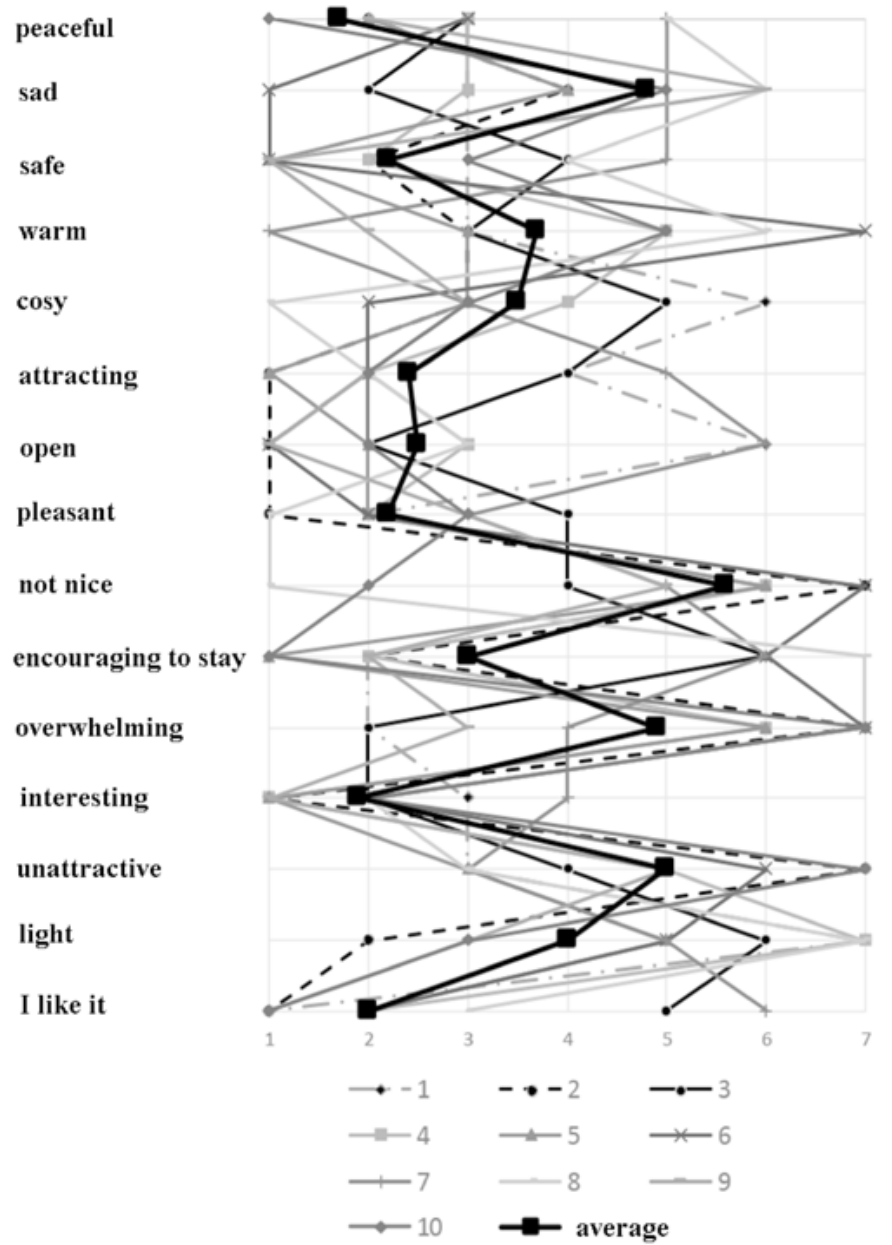

disturbing

cheerful

dangerous

cold

not cosy

repellent

closed

unpleasant

nice

not encouraging to stay

not overwhelming

boring

attractive

heavy

I don't like it

Fig. 4. Group 2-VR the results of the study (own elaboration) 

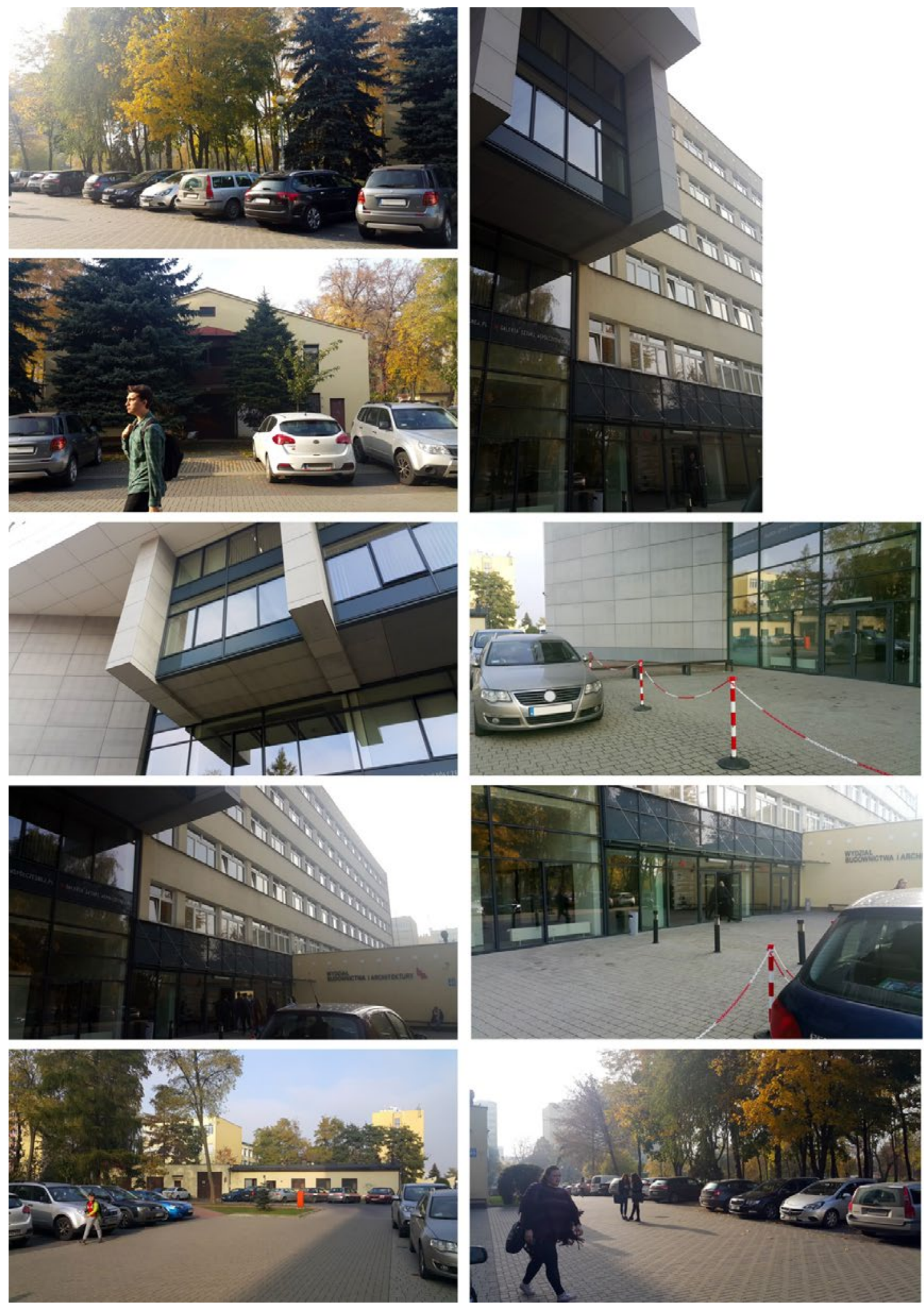

Fig. 5. A set of photos presented to the group 3 (author's own pictures) 


\section{Group 3}

The third group received a set of pictures of the square. The surveys were completed in the classroom. The students had only these photographs at their disposal (Fig. 5.) throughout the period of the survey. A room where the survey took place has no windows to the square.

The results presented in Fig. 6. show the assessed square as an interesting, pleasing, attractive place that the respondents like.

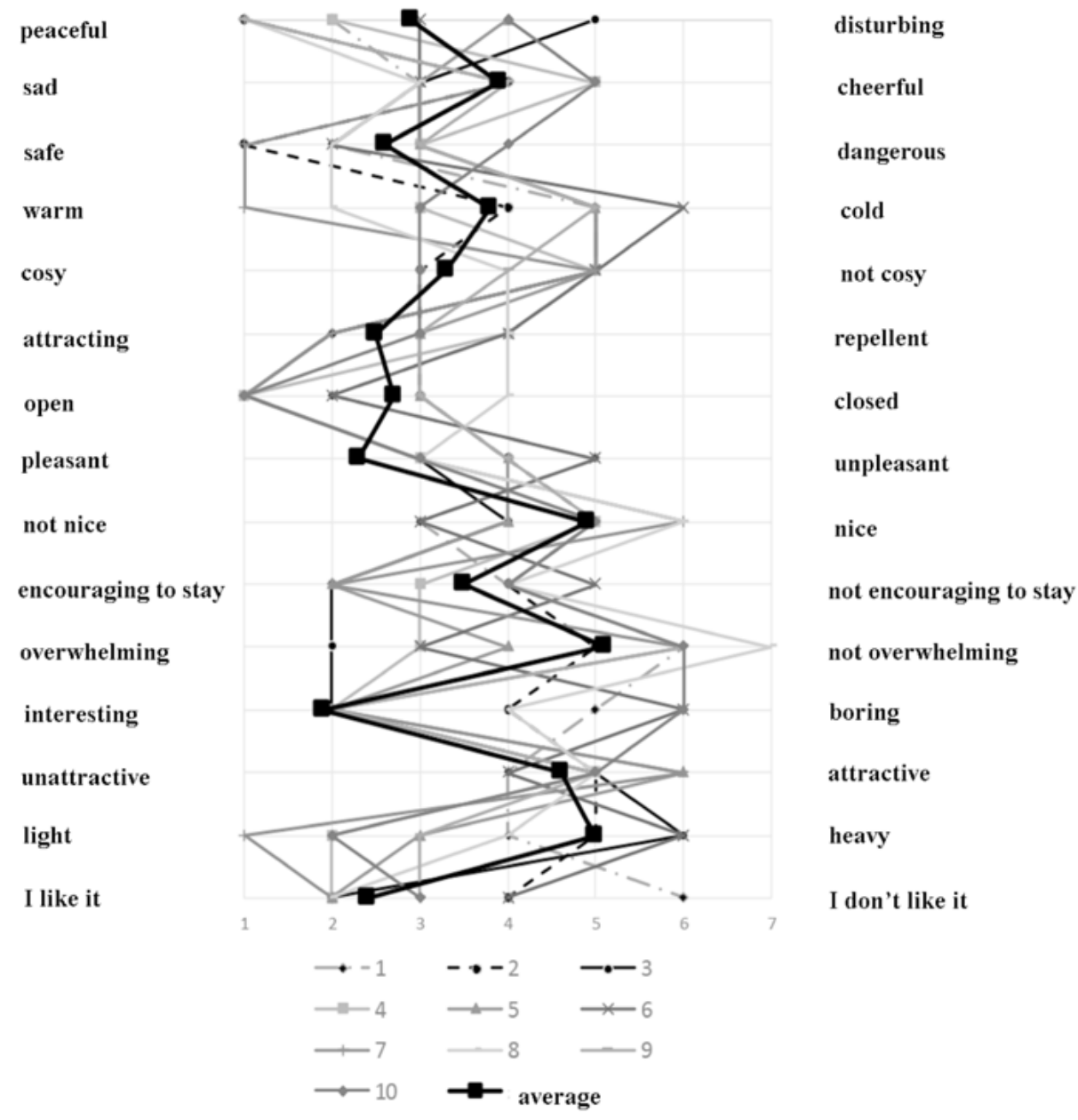

Fig. 6. The group $3-a$ set of photos - the results of the study (own elaboration)

\section{Comparison of results}

The average results of each group were compiled on a single graph (Fig. 7.).

The points of the group 1 (on-site survey) and the group 2 (virtual reality) are close in many places. Standard deviation for these two results varies from 0 (interesting / boring) to 1.2 (calm / disturbing). The average of this deviation is 0.43 , whereas this result for the comparison of the group 1 and group 3 (a set of photos) is 0.69 . Differences in comparison of group 1 and 3 responses range from 0 (attractive / unattractive) to 1.6 (interesting / boring). 


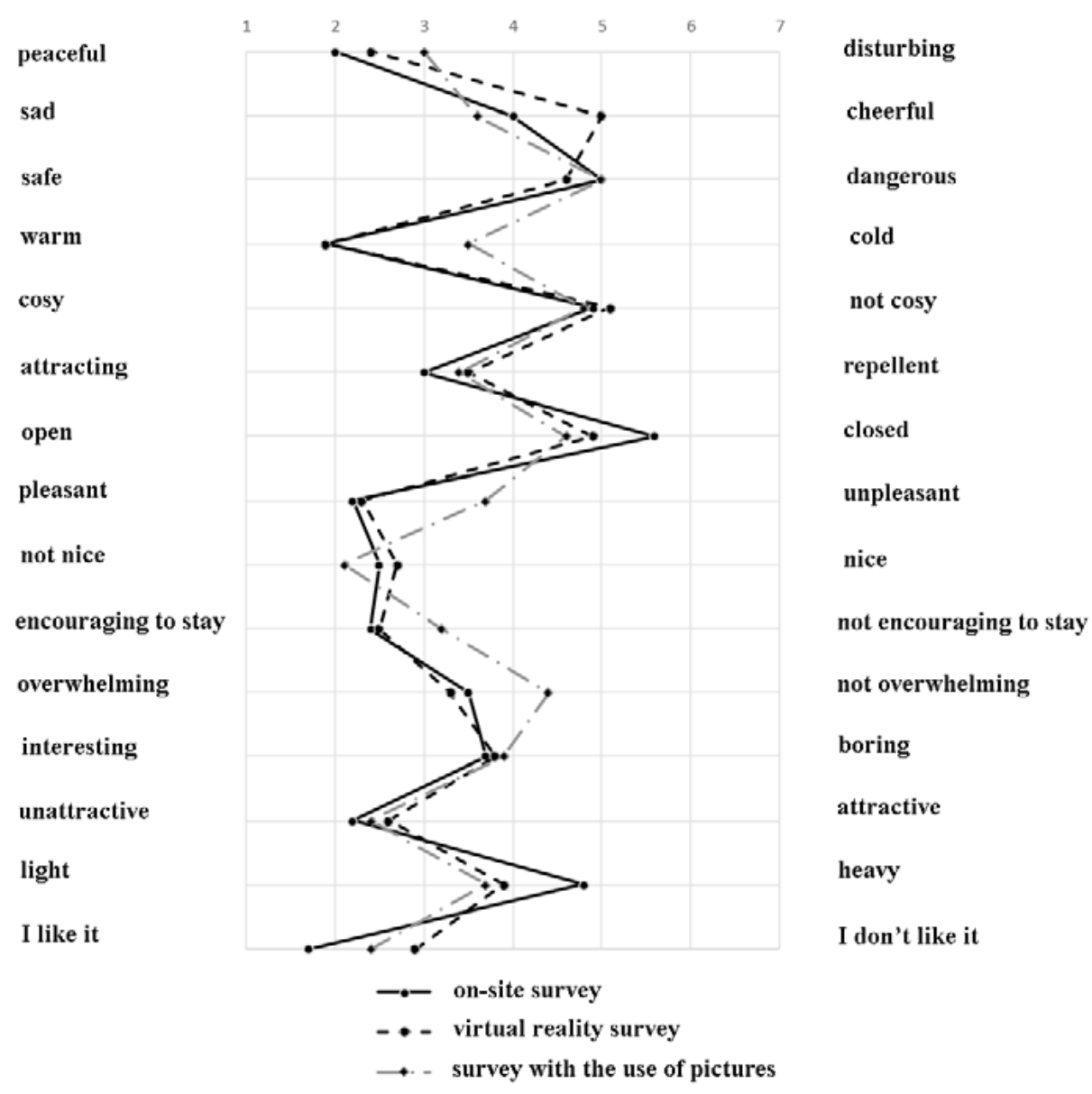

Fig. 7. Compilation of the results for all groups (own elaboration)

The students assessed the square as a peaceful, safe, attractive, open, interesting and pleasant place that they like. Answers where the respondents were least convinced in assessing the qualities of the square were: warm / cold, light / heavy and encouraging / not encouraging to stay.

\section{Summary}

It seems that the presented research method can be used to study the perception of buildings (architecture) and space (places), not only those that are already built, but also those existing only in the virtual world (computer games, films, architectural and urban designs). However, in order to clearly confirm the possibility of its use, further research should be carried out on a larger group of respondents and concerning different places.

If subsequent tests confirm the correlation of the results obtained during the on-site survey and virtual reality survey, the virtual reality could be used to check already at the design stage how transformation of a given space may be perceived by the users. This can be especially significant if they concern the historical substance of the city or important city squares.

\section{Literature}

[1] Alexander Ch., 2008: Język wzorców, Gdańskie Wydawnictwo Psychologiczne, Sopot

[2] Asanowicz A., 2014: The phenomenology and philosophy of simulacra influence on the VR, Architecturae et Artibus, $6(2014), 5-8$ 
[3] Bil, J., 2013: Tożsamość obiektów architektonicznych w środowisku wirtualnym, Przestrzeń i Forma 20 (2013) $113-124$

[4] Grabowski A., 2015: Zwiększenie realizmu symulacji w środowisku wirtualnym dzięki wykorzystaniu zmysłu dotyku, Mechanik 7 (2015) 251-258

[5] Gradziński P., 2015: Przestrzeń cyfrowa - arealny nowy świat, ARCHITECTURAE et ARTIBUS - 1/2015, 25-35

[6] Lenartowicz, J. K., 1990: O psychologii architektury. Próba inwentaryzacji badań, określenie zakresu przedmiotowego i wpływu na architekturę, Bioarchitektura - zagadnienia społeczne: materiały I Międzynarodowego Sympozjum, Szczecin, $115-118$

[7] Lenartowicz, J. K., 1992: O psychologii architektury : próba inwentaryzacji badań, zakres przedmiotowy i wpływ na architekturę, Kraków

[8] Lenartowicz, J. K., 2010: Słownik psychologii architektury dla studiujących architekturę : skrypt dla studentów wyższych szkół technicznych, Kraków

[9] Oseńko, M. Smołka, J. Skublewska-Paszkowska, M. Łukasik, E., 2017: A method for visualization of 3D motion data using a mobile device, Informatyka, Automatyka, Pomiary w Gospodarce i Ochronie Środowiska 3/2017, 37-42

[10] Osgood Ch. E., 1952: The Nature and Measurement of Meaning, Psychological Bulletin, 49 (1952), 197-237

[11] Pallasmaa J., 2012: Oczy skóry, Instytut Architektury, Kraków.

[12] Pardel, P., 2009: Przegląd ważniejszych zagadnień rozszerzonej rzeczywistości, Studia Informatica, 1 (30), 35 -64

[13] Rasmussen S.E., 1999: Odczuwanie architektury, Biblioteka architekta, Wyd. MURATOR, Warszawa

[14] Wrana J., 2011: Tożsamość miejsca. Kryterium w projektowaniu architektonicznym, Wydawnictwo Politechniki Lubelskiej, Lublin.

[15] Wrana J., Fitta A., 2012a: Architektura a kontekst miejsca, Budownictwo i Architektura 11, 5-13

[16] Wrana J., Fitta A., 2013: The innovative solutions in new building for education architects in Lublin, Budownictwo i Architektura 12(4), 145-150

[17] Wrana J., 2012b: Eseje o tożsamości miejsca. Wybrane artykuły dotyczące tożsamości i kontekstu. Wydawnictwo Politechniki Lubelskiej, Lublin

[18] Zumthor P., 2010: Myślenie Architekturą, Wyd. Karakter, Kraków,.

[19] Żórawski J., 2008: O budowie formy architektonicznej, w: K. Wilkoszewska (ed.), Wybór pism estetycznych, Universitas, Kraków.

\section{Sposób odbioru placu przed budynkiem Wschodniego Centrum Architektury Politechniki Lubelskiej a reakcje emocjonalne badanych}

\footnotetext{
Streszczenie: W artykule przedstawiony jest opis metody badawczej oraz wyniki badań dotyczących różnicy odbioru przestrzeni w zależności od sposobu jej postrzegania.

Badania dotyczyły jednej przestrzeni (plac przed budynkiem Wschodniego Innowacyjnego Centrum Architektury Politechniki Lubelskiej) i trzech różnych sposób odbioru. Jedna grupa badanych była fizycznie na placu, druga wirtualnie - dzięki użyciu technologii virtual reality (VR), trzeciej były przedstawione zdjęcia. Każda z grup respondentów wybierała bliższe im emocje z opracowanej na potrzeby tego badania skali semantycznej. Wyniki grup zostały porównane, a wnioski zostały przedstawione w podsumowaniu.

Badanie zostało przeprowadzone w celu sprawdzenia możliwości użycia technologii VR i zdjęć do badań emocji, jakie powstają w odbiorcy danej przestrzeni.
}

Słowa kluczowe: wirtualna rzeczywistość, odbiór architektury, emocje w architekturze, psychologia architektury, dyferencjał semantyczny 